\title{
Individual sensitivity to cytogenetic effects of benzo[ $\alpha]$ pyrene in cultured human lymphocytes: Influence of glutathione S-transferase M1 genotype
}

\author{
Gülgün S. Güven, Mehmet Güven, Ilhan Onaran, Turgut Ulutin and Seniha Hacihanefioglu \\ University of Istanbul,Cerrahpasa Faculty of Medicine, Department of Medical Biology, Istanbul, Turkey.
}

\begin{abstract}
Sister chromatid exchange (SCE) and chromosome aberrations (CA) in peripheral lymphocytes has been widely used in assessing exposure to mutagens and carcinogens. One of the extensively studied genotoxins is benzo[ $\alpha$ ]pyrene $(\mathrm{BaP})$. We studied the ability of $\mathrm{BaP}$ to induce SCE and CA in 16 glutathione S-transferase M1 (GSTM1)-positive and 15 GSTM1-null individuals by analyzing 72-h whole-blood lymphocyte cultures, either BaP-untreated (controls) or treated with $5 \mu \mathrm{M}$ of BaP for 24 or $48 \mathrm{~h}$. There was no differences in the level of $\mathrm{BaP}$-induced chromosomal aberrations between GSTM1-positive or null individuals when the cells were BaPexposed for $24 \mathrm{~h}(0.083 \pm 0.059 \mathrm{vs} .0 .090 \pm 0.058)$ or $48 \mathrm{~h}(0.092 \pm 0.057 \mathrm{vs} .0 .096 \pm 0.050$. The frequency of SCE in controls was GSTM1-positive $=2.96 \pm 0.35$ and GSTM1-null $=3.23 \pm 0.56$ while that for BaP-treated lymphocytes was GSTM1-positive $=5.56 \pm 0.83$ and GSTM1-null $=6.09 \pm 1.11$ and were not statistically significant. The rates of BaP-induced in vitro chromatid and chromosome-type gaps and breaks were similar in all groups, although GSTM1-null genotype chromatid-type breaks were more frequent $(0.064 \pm 0.039$ per metaphase) than chromosome-type breaks $(0.032 \pm 0.027$ per metaphase) after $48 \mathrm{~h}$ treatment with $\mathrm{BaP}(\mathrm{p}<0.001)$. These findings suggest that BaP-induced in vitro SCE and CA are not influenced by the GSTM1 genotype.
\end{abstract}

Key words: sister chromatid exchanges, chromosomal aberrations, benzo[ $\alpha]$ pyrene, glutathione S-transferase M1.

Received: November 22, 2004; Accepted: May 31, 2005.

\section{Introduction}

Cytogenetic tests such as those for chromosome aberration and sister chromatid exchange are most often applied in biomonitoring of the genotoxicity of potentially carcinogenic chemicals in peripheral blood lymphocytes. The polycyclic aromatic hydrocarbon benzo $[\alpha]$ pyrene $(\mathrm{BaP}$; 3,4-Benzpyrene) is a classic DNA-damaging carcinogen (Gupta et al., 1988) commonly found in tobacco smoke and the environment. Epidemiologic studies have shown that exposure to $\mathrm{BaP}$ increases the risk of cancer in the lungs, stomach, bladder and skin (Nadon et al., 1995; Vineis and Caporaso, 1995), although because not all exposed individuals develop cancer genetically determined host factors may contribute to predisposition to DNA damage (Pastorelli et al., 1998) and therefore modulate the risk of cancer.

It is known that $\mathrm{BaP}$ is a pro-carcinogen requiring metabolic activation (Gelboin, 1980) and that a large number of $\mathrm{BaP}$ metabolites are produced in phytohemagglutinin-stimulated human lymphocytes, including $7 \beta, 8 \alpha$-di-

Send correspondence to Gülgün S. Güven. Incirli-Osmaniye yolu, Yesil su sok, Inci sitesi E Blok, Daire 5, 34730 Bakyrköy, Istanbul, Turkey. E-mail: gsguven@istanbul.edu.tr; gmguven@ttnet.net.tr. hydroxy-9 $\alpha, 10 \alpha$-epoxy-7,8,9,10-tetrahydrobenzo[ $\alpha]$ pyrene (BPDE) and 4,5-dihydroxy-4,5-dihydrobenzo[ $\alpha]$ pyrene (Okano et al., 1979). The BaP metabolites produced by metabolic activation are highly variable and probably depend on specific activation and detoxification enzymes present in $\mathrm{BaP}$-exposed cells.

Glutathione S-transferases (GSTs) belong to a superfamily of multifunctional isoenzymes that contribute to the detoxification process through several different mechanisms (Hayes and Pulford, 1995). Mammalian cytosolic GSTs have been grouped into at least six classes (Alpha, $\mathrm{Mu}, \mathrm{Pi}$, Theta, Sigma and Zeta) based on sequence similarities and since GTSs function widely in the metabolic detoxification of xenobiotics genetic polymorphism could play an important role in determining individual sensitivity to reactive chemicals. In humans GST Mu 1 (GTSM1), a member of the GST Mu class, is polymorphic, with about half of the Caucasian population being homozygous for a deleted GSTM1 gene (GSTM1-null) and therefore fail to express the protein (Board et al., 1990). The results of experimental studies indicate that GSTM1 is a marker of susceptibility to the induction of cytogenetic damage by a certain class of mutagens (Nielsen et al., 1996; Wiencke et al., 1990), lack of the GSTM1 isoform being associated with 
reduced efficiency in binding genotoxic substrates, including epoxides deriving from PAHs and aflatoxins (Hayes and Pulford, 1995). The null allele produces no enzyme and previous studies have shown a possible link between the GSTM1-null phenotype and susceptibility to cancer, particularly lung cancer (Harrison et al., 1997; Zhong et al., 1993). Several studies have suggested that the prevalence of lung cancer in a large case-controlled study in Turkey is quite common $(38.6 \%$ of cancers in males) and that the GSTM1-null genotype is a risk factor for the development of lung cancer for the Turkish population (Fidaner et al., 2001, Pinarbasi et al., 2003).

To our knowledge, there is no conclusive in vitro data on the effect of GSTM1 deficiency on the cytogenetic damage induction by BaP. The aim of our study was to examine the ability of $\mathrm{BaP}$ to induce different individual cytogenetic responses measured by sister chromatid exchange and the frequency of chromosome aberrations taking into account the possible influence of GSTM1 polymorphism.

\section{Materials and methods}

\section{Participants}

The experiments were conducted on human whole blood lymphocytes obtained by veinipuncture from 16 female and 15 male $(\mathrm{n}=31)$ Caucasian volunteers from Istanbul, 16 (eight of each sex) being GSTM1-positive and 15 (seven men, eight women) being GSTM1-null, with a mean age of 23.4 (range 18-35) years. The group was matched according to age, sex, smoking habits, coffee and alcohol consumption and occupation, all of which could influence the cytogenetic results. All volunteers were healthy nonsmokers with no history of alcohol or coffee addiction and had not been exposed to any specific mutagens (e.g. X-rays, medicines) for 3 months prior to the cytogenetic examination. The research was authorized by the ethics committees of our institutions and informed consent was obtained from the participants before the sampling.

\section{Laboratory reagents}

Standard lymphocyte culture reagents were purchased from Gibco Laboratory (Grand Island, NY) while 5Bromo-2-deoxyuridine (BrdU), benzo[a]pyrene (BaP) and other standard laboratory reagents were purchased from Sigma Chemical (St. Louis, MO). All other chemicals used in the study were of the highest purity available from commercial sources. Taq DNA polymerase and 2'- deoxyribonucleoside-5'-triphosphates were purchased from Epicentre Technologies (Madison, WI). The primers were purchased from Operon Technologies (Alameda, CA).

\section{Extraction of DNA and detection of the GSTM1 polymorphism}

For each sample, DNA was extracted from the peripheral lymphocytes present in EDTA anticoagulated blood by proteinase $\mathrm{K}$ digestion and salting out with saturated aqueous $\mathrm{NaCl}$ (Miller et al., 1988). Presence or absence of the GSTM1 gene was determined by the polymerase chain reaction (PCR) method described by Zhong et al. (1993), the GSTM1 primers being 5'-GAACTCCCTGA AAAGCTAAAGC-3' (forward) and 5'-GTTGGGCTCA AATA TACGGTGG-3' (reverse) and the product $215 \mathrm{bp}$ Beta-globulin was also tested for because the absence of GSTM1 amplification product in the presence of the betaglobulin PCR product indicates a GSTM1-null genotype. The beta-globulin primers used were 5'-CAACTTCATC CA CGTTCACC-3' (forward) and 5'-GAAGAGCCAAG GACAGGTAC-3' (reverse) and the product 268-bp.

\section{Sister chromatid exchange analysis}

For each blood sample lymphocyte cultures were prepared using $0.5 \mathrm{~mL}$ of heparinized whole blood added to $4.5 \mathrm{~mL}$ of RPMI 1640 culture medium (Gibco, Grand Island, NY, USA) supplemented 1\% v/v L-glutamine, 20\% $\mathrm{v} / \mathrm{v}$ fetal calf serum, 100 international units $/ \mathrm{mL}$ of penicillin, $100 \mu \mathrm{g} / \mathrm{mL}$ streptomycin, $1.5 \% \mathrm{w} / \mathrm{v}$ phytohemagglutinin and $10 \mu \mathrm{M}$ of BrdU and the culture incubated at $37^{\circ} \mathrm{C}$ for $72 \mathrm{~h}$ after which $0.2 \mu \mathrm{g} / \mathrm{mL}$ of colchicine was added $2 \mathrm{~h}$ prior to harvesting the lymphocytes. Duplicate sets of cultures were made from each blood sample, one set to serve as control and the other for the experiments with $\mathrm{BaP}$.

For the $\mathrm{BaP}$ experiments $5 \mu \mathrm{M}$ of $\mathrm{BaP}$ dissolved in DMSO was added to the experimental group of cultures $24 \mathrm{~h}$ after the start of incubation, which proceeded up to $72 \mathrm{~h}$ as for the control cultures. We also added DMSO to the control cultures at a final concentration of not in excess of $0.1 \% \mathrm{v} / \mathrm{v}$. During the $48 \mathrm{~h}$ of exposure to $\mathrm{BaP}$ and/or DMSO there was no significant change in the lymphocyte death rate. Techniques for cell harvest and slide preparation followed conventional procedures (Tucker et al., 1993). Briefly, the cells were harvested by centrifugation, lysed by in $0.075 \mathrm{M} \mathrm{KCl}$, fixed in 3:1 (v/v) methanol:acetic acid and air-dried slides prepared and stained with 5\% Giemsa solution in freshly made Sörenson's buffer ( $\mathrm{pH}$ 10.4) for $12 \mathrm{~min}$. The sister chromatid exchange frequency per sample was assessed by scoring the number of sister chromatid exchanges in 25 complete second metaphases.

\section{Chromosome aberration analysis}

Whole blood cultures were established as described above except that no BrdU was added and lymphocytes were treated with $5 \mu \mathrm{M}$ BaP $24 \mathrm{~h}$ and $48 \mathrm{~h}$ after the start of culture. The control cultures received DMSO as described above. Metaphase chromosome analysis for the detection of chromosomal aberrations was performed according to the method of Moorehead et al. (1960), lymphocytes being harvested and air-dried preparations Giemsa-stained and scored for chromosome aberrations. For each sample in the experimental and control group a total of 50 well-spread 
metaphases were analyzed per treatment for chromatid and chromosome aberrations (breaks and gaps).

\section{Statistical analysis}

All tests were performed in duplicate, and the results were expressed as means \pm their standard deviation (SD). The results were evaluated using the student's t-test for dependent and independent groups at $\mathrm{p}=0.05$.

\section{Results}

\section{Sister chromatid exchange analysis}

The effect of $\mathrm{BaP}$ on the induction of sister chromatid exchange in lymphocytes is presented in Table 1 . In both genotype groups, treatment of blood lymphocytes with $\mathrm{BaP}$ caused a significant increase in the frequency of sister chromatid exchange compared with the controls $(p<0.001)$. The sister chromatid exchange response of the GSTM1-positive and the GSTM1-null donors did not differ from each other in either the treated or control cultures $(p>0.05)$. Although slightly higher individual sister chromatid exchange responses were observed in the control and BaP-treated cultures for the GSTM1-null donors compared

Table 1 - Influence of GSTM1 genotype on sister chromatid exchange induction by benzo[ $\alpha]$ pyrene $(\mathrm{BaP})$.

\begin{tabular}{lccc}
\hline $\begin{array}{l}\text { GSTM1 } \\
\text { genotype }\end{array}$ & $\begin{array}{c}\text { Number of } \\
\text { individuals }\end{array}$ & $\begin{array}{c}\text { Number of sister chromatid exchanges } \\
\text { per metaphase } \\
\text { (mean } \pm \text { standard deviation) }\end{array}$ \\
\cline { 3 - 4 } Positive & 16 & $2.96 \pm 0.35$ & $5.56 \pm 0.83^{\mathrm{a}}$ \\
Null & 15 & $3.23 \pm 0.56$ & $6.09 \pm 1.11^{\mathrm{a}}$ \\
\hline
\end{tabular}

${ }^{\mathrm{a}}$ significant at $\mathrm{p}<0.001$ when compared with control cultures without $\mathrm{BaP}$ with the GSTM1-positive donors these differences were not statistically significant at $\mathrm{p}=0.05$.

\section{Chromosome aberration analysis}

In both genotypes there was a statistically significant increase $(p<0.001)$ in structural chromosome aberrations such as chromatid and chromosome gaps and breaks in BaP-treated metaphases as compared to untreated controls but there was no statistically significant $(p>0.05)$ difference between treatment times (Table 2). The frequency of chromatid and chromosome gaps and breaks were similar ( $\mathrm{p}>0.05)$ in all the groups, although in GSTM1-null lymphocytes treated with BaP for $48 \mathrm{~h}$ gaps and breaks were more prevalent in chromatids than chromosomes $(\mathrm{p}<0.05)$. Neither the BaP-treated cells (24 and $48 \mathrm{~h}$ treatment) nor the controls showed any statistical difference ( $\mathrm{p}>0.05)$ in chromosome aberrations between GSTM1positive and GSTM1-null genotypes.

\section{Discussion}

In this in vitro study we used two cytogenetic endpoints (sister chromatid exchange and chromosome aberrations) to investigate the relationship between BaP-induced cytogenetic damage and GSTM1 polymorphism in human lymphocytes.

Although $\mathrm{BaP}$ itself is relatively non-toxic it is bioactivated in vivo by cytochrome $\mathrm{P} 450$ and peroxidases generating highly toxic electrophilic and free radical reactive intermediates such as BPDE which can irreversibly damage DNA by covalent binding or oxidation (Sullivan, 1985) and which has high specificity for GSTM1 (Seidegard and Ekström, 1997). Lymphocytes posses GSTM1 activity and are subject to oxidative stress when exposed to various factors (Seidegard and Pero, 1985) and have been extensively

Table 2 - Chromosome aberrations after 24 and $48 \mathrm{~h}$ exposure to benzo[ $\alpha]$ pyrene $(\mathrm{BaP})$.

\begin{tabular}{|c|c|c|c|c|}
\hline \multirow[t]{2}{*}{$\begin{array}{l}\text { GSTM1 genotype, treatment } \\
\text { and } \mathrm{BaP} \text { exposure time }(\mathrm{h})\end{array}$} & \multirow[t]{2}{*}{$\begin{array}{c}\text { Total } \\
\text { aberrations }\end{array}$} & \multirow[t]{2}{*}{$\begin{array}{l}\text { Total aberrations per metaphase } \\
\text { (mean } \pm \text { standard deviation) }\end{array}$} & \multicolumn{2}{|c|}{$\begin{array}{l}\text { Aberration per metaphase type } \\
\text { (mean } \pm \text { standard deviation) }\end{array}$} \\
\hline & & & Chromatid & Chromosome \\
\hline \multicolumn{5}{|l|}{ Positive, 16 individuals } \\
\hline $\mathrm{BaP}-24 \mathrm{~h}$ & 67 & $0.083 \pm 0.059^{\mathrm{a}}$ & $0.036 \pm 0.027^{\mathrm{a}}$ & $0.047 \pm 0.047^{\mathrm{a}}$ \\
\hline $\mathrm{BaP}-48 \mathrm{~h}$ & 74 & $0.092 \pm 0.057^{\mathrm{a}}$ & $0.050 \pm 0.041^{\mathrm{a}}$ & $0.042 \pm 0.037^{\mathrm{a}}$ \\
\hline Control-24 h & 13 & $0.017 \pm 0.022$ & $0.009 \pm 0.012$ & $0.008 \pm 0.012$ \\
\hline Control-48 h & 13 & $0.017 \pm 0.025$ & $0.009 \pm 0.016$ & $0.008 \pm 0.016$ \\
\hline \multicolumn{5}{|l|}{ Null, 15 individuals } \\
\hline $\mathrm{BaP}-24 \mathrm{~h}$ & 69 & $0.090 \pm 0.058^{\mathrm{a}}$ & $0.045 \pm 0.039^{\mathrm{a}}$ & $0.044 \pm 0.025^{\mathrm{a}}$ \\
\hline $\mathrm{BaP}-48 \mathrm{~h}$ & 72 & $0.096 \pm 0.050^{\mathrm{a}}$ & $0.064 \pm 0.039^{\mathrm{a}, \mathrm{b}}$ & $0.032 \pm 0.027^{\mathrm{a}}$ \\
\hline Control-24 h & 14 & $0.018 \pm 0.027$ & $0.009 \pm 0.016$ & $0.009 \pm 0.016$ \\
\hline Control-48 h & 12 & $0.016 \pm 0.025$ & $0.008 \pm 0.012$ & $0.008 \pm 0.014$ \\
\hline
\end{tabular}

a significant at $\mathrm{p}<0.001$ when compared with control cultures.

${ }^{\mathrm{b}}$ significant at $\mathrm{p}<0.05$ when compared with chromosome type (chromatid versus chromosome). 
used as a convenient tissue source for investigating the cytotoxicity of xenobiotics. If the GSTM1 isotype is involved in defense against oxidative stress then GSTM1-null lymphocytes should be more susceptible to genotoxic and cytotoxic damage but in our study there was no statistically significant difference between GSTM1-null and GSTM1positive lymphocytes in terms of the frequency of sister chromatid exchange or chromosome aberrations. Our results support those of Onaran et al. (2001) which suggest that lack of the GSTM1 gene does not influence micronuclei induction by $\mathrm{BaP}$ in human lymphocyte cultures.

Only a limited number of in vitro studies have been performed using cytogenetic biomarkers to investigate the role of GSTM1 polymorphism on sensitivity to $\mathrm{BaP}$. A study by Salama et al. (2001) showed an increase in BaPinduced chromosome aberrations but not sister chromatid exchange in GSTM1-null lymphocytes. However, when Xiong et al. (2001) investigated the role of null GSTM1 and GSTT1 (GST Theta 1) genotypes on BPDE-induced chromosomal aberrations in peripheral blood lymphocytes from women with breast cancer and matched controls they found that the GSTM1-null genotype was not associated with an increased tendency to form chromosomal aberrations in either the breast-cancer or the control group. These different results in terms of chromosome aberrations may be due to the different experimental conditions used in the different studies such as the concentration and duration of BaP-treatment, the use of BPDE instead of $\mathrm{BaP}$, the type of detection methods used (Salama et al. (2001) used the fluorescence in situ hybridization (FISH) assay in their study), the influence of combined genotypes involved in $\mathrm{BaP}$ metabolism (Salama et al. (2001) used the GSTM1-null/EH4 (epoxide hydrolase 4) genotypes) and the effects of DNA repair. A recent study by Pastorelli et al. (2002) demonstrated that the XPD (xeroderma pigmentosum group D) genotype in combination with the GSTM1-null genotype significantly influenced the percentage detectability and levels of BPDE-DNA in white blood cells.

There have been other studies with $\mathrm{BaP}$ which have addressed the relationship between GSTM1 polymorphism and some biomarkers present in humans exposed to polycyclic hydrocarbons, but it remains unclear whether or not GSTM1 polymorphism modulates in vivo BaP genotoxicity or carcinogenicity in humans. Our results agree with cytogenetic studies on people who have been environmentally or occupationally to exposed polycyclic hydrocarbons have shown no difference in the levels of cytogenetic markers between GSTM1-null and GSTM1-positive genotypes (Binkova et al., 1996; Carstensen et al., 1993; Kalina et al., 1998). However, studies involving DNA adducts in people exposed to polycyclic hydrocarbons have reported that the type of GSTM1 genotype, either alone or in combination with other genotypes, influences DNA adduct levels (Ichiba et al., 1994; Topinka et al., 1997) although other studies have shown no such GSTM1-dependent differences (Binkova et al., 1996; Mooney et al., 1997).

Our findings support the work of Wei et al. (1996), who found that that $\mathrm{BaP}$ increased chromosomal aberrations in human lymphocytes. It is not only the increase in the frequency of structural chromosome aberrations but also their type and distribution which are important. The type of aberrations induced by genotoxic agents are cellcycle dependent, with most chemically induced aberrations being formed only during DNA synthesis, probably due to misreplication. Chemical agents induce mainly chromatid-type aberrations and are also very efficient in inducing sister chromatid exchange (Natarajan, 1993). The exact mechanism of how $\mathrm{BaP}$ induces chromosomal aberrations remains unclear, although it is known that $\mathrm{BaP}$-induced DNA damage is repaired mainly by nucleotide excision repair (NER) . During the repair process, it is likely that delayed completion of initial nicking of DNA strands by NER may induce DNA strand breaks that eventually lead to chromatid breaks (Tang et al., 1992). Our study showed that although the rates of in vitro BaP-induced chromatid and chromosome-type gaps and breaks were generally similar in all the groups, chromatid-type breaks were significantly more frequent $(\mathrm{p}<0.05)$ than chromosome-type breaks in GSTM1-null lymphocytes after $48 \mathrm{~h}$ treatment with BaP. The conversion of BaP to DNA-reactive metabolites is dependent on a cascade of biotransformations and BaP metabolites, which are substrates for GSTM1, might be active during long-term exposure to $\mathrm{BaP}$, suggesting that higher levels of chromatid-type breaks may occur in individuals with the GSTM1-null genotype. Indeed, it has been reported that the amount of $\mathrm{BaP}$ metabolized is significantly increased by incubating mitogen-stimulated lymphocytes with BaP for between 24 and $72 \mathrm{~h}$ (Gurtoo et al., 1980; Thompson et al., 1989).

In summary, our results indicate that lack of the GSTM1 gene does not influence the in vitro genotoxicity or cytotoxicity of $\mathrm{BaP}$ in human lymphocytes. However, the question of whether the GSTM1 genotype influences in vitro BaP-induced cytogenetic damage is difficult to answer because the presence of other susceptibility genes may modify the effect of the GSTM1-null. Further research is warranted to confirm our findings and investigate possible risk modulation by genetic polymorphisms of carcinogenmetabolizing enzymes and DNA repair genes that are relevant to the phenotype.

\section{Acknowledgments}

This work was supported by the Research Fund of The University of Istanbul, project number 1231/181298.

\section{References}

Binkova B, Lewtas J and Mìskova I (1996) Biomarker studies in northern Bohemia. Environ Health Perspect 104:591-597. 
Board P, Coggan M, Johnston P, Ross V, Suzuki T and Webb G (1990) Genetic heterogeneity of the human glutathione transferases: A complex of gene families. Pharm Ther 48:357-369.

Carstensen U, Alexandrie AK and Hoegstedt B (1993) B- and T-lynphocyte micronuclei in chimney sweeps with respect to genetic polymorphism for CYP1A1 and GST1 (class $\mathrm{Mu}$ ). Mutat Res 289:187-195.

Fidaner C, Eser SY and Parkin DM (2001) Incidence in Izmir in 1993-1994: First results from Izmir Cancer Registry. Eur J Cancer 37:83-92.

Gelboin HV (1980) Benzo[ $\alpha]$ pyrene metabolism, activation, and carcinogenesis: Role and regulation of mixed-function oxidases and related enzymes. Physiol Rev 60:1107-1166.

Gupta R, Earley C and Sharma S (1988) Use of human peripheral blood lymphocytes to measure DNA binding capacity of chemical carcinogens. Proc Natl Acad Sci USA 85:35133517.

Gurtoo HL, Vaught JB, Marinello AJ, Paigen B, Gessner T and Bolanowska W (1980) High-pressure liquid chromatographic analysis of benzo(a)pyrene metabolism by human lymphocytes from donors of different aryl hydrocarbon hydroxylase inducibility and antipyrine half-lives. Cancer Res 40:1305-1310.

Harrison DJ, Cantlay AM, Rae F, Lamb D and Smith CA (1997) Frequency of glutathione S-transferase M1 deletion in smokers with emphysema and lung cancer. Hum Exp Toxico 16:356-360.

Hayes JD and Pulford DJ (1995) The glutathione S-transferase supergene family regulation of GST and the contribution of the isoenzymes to cancer chemoprotection and drug resistance. Crit Rev Biochem Mol Biol 30:445-600.

Ichiba M, Hagmar L and Rannug A (1994) Aromatic DNA adducts, micronuclei and genetic polymorphism for CYP1A1 and GSTM1 in chimney sweeps. Carcinogenesis 15:13471352.

Kalina I, Brezani P and Gajdosova D (1998) Cytogenetic monitoring in coke oven workers. Mutat Res 417:9-17.

Miller SA, Oykes DD and Polesky MF (1988) A simple salty out procedure for extracting DNA from human nucleated cells. Nucleic Acids Res 16:1215.

Mooney LV, Bell DA, Santella RM, Van Bennekum AM, Ottman R, Paik M, Blaner WS, Lucier GW, Covey L, Young TL, Cooper TB, Glassman H and Perera FP (1997) Contribution of genetic and nutritional factors to DNA damage in heavy smokers. Carcinogenesis 1997:503-509.

Moorehead PS, Nowell PC, Mellman WJ, Battips DM and Hungerford DA (1960) Chromosome preparations of leukocytes cultured from human peripheral blood. Exp Cell Res 20:613-616.

Nadon L, Siemiatycki J, Dewar R, Krewski D and Gerin M (1995) Cancer risk due to occupational exposure to polycyclic aromatic hydrocarbons. Am J Ind Med 28:303-24.

Natarajan AT (1993) Mechanisms for induction of mutations and chromosome alterations. Environ Health Perspect 101:225229.

Nielsen PS, De Pater N, Okkels H and Autrup H (1996) Environmental air pollution and DNA adducts in Copenhagen bus drivers - Effect of GSTM1 and NAT2 genotypes on adduct levels. Carcinogenesis 17:1021-1027.
Okano P, Miller HN, Robinson RC and Gelboin HV (1979) Comparison of benzo[ $\alpha]$ pyrene and (-)trans-7,8-dihydroxy-7,8dihydrobenzo $[\alpha]$ pyrene metabolism in human blood monocytes and lymphocytes. Cancer Res 39:3184-3193.

Onaran I, Güven G, Ozaydin A and Ulutin T (2001) The influence of GSTM1-null genotype on susceptibility to in vitro oxidative stress. Toxicology 157:195-205.

Pastorelli R, Guanci M, Cerri A, Negri E, La Vecchia C, Fumagalli F, Mezzetti M, Cappelli R, Panigalli T, Fanelli R and Airoldi L (1998) Impact of inherited polymorphisms in glutathione S-transferase M1, microsomal epoxide hydrolase, cytochrome P450 enzymes on DNA, and blood protein adducts of benzo(a)pyrene-diolepoxide. Cancer Epidemiol Biom Prevent 7:703-709.

Pastorelli R, Cerri A, Mezzetti M, Consonni E and Airoldi L (2002) Effect of DNA repair gene polymorphisms on BPDE-DNA adducts in human lymphocytes. Int J Cancer 100:9-13.

Pinarbasi H, Silig Y, Cetinkaya O, Seyfikli Z and Pinarbasi E (2003) Strong association between the GSTM1-null genotype and lung cancer in a Turkish population. Cancer Genet Cytogenet 146:125-9.

Salama SA, Sierra-Torres CH, Oh HY, Hamada FA and Au WW (2001) Variant metabolizing gene alleles determine the genotoxicity of benzo[a]pyrene. Environ Mol Mutagen 37:17-26.

Seidegard J and Pero RW (1985) The hereditary transmission of high glutathione transferase activity towards trans-stilbene oxide in human mononuclear leukocytes. Hum Genet 69:66-68.

Seidegard J and Ekström G (1997) The role of human glutathione transferases and epoxide hydrolases in the metabolism of xenobiotics. Environ Health Perspect 105:791-799.

Sullivan PD (1985) Free radicals of benzo(a)pyrene and derivatives. Environ Health Prospect 64:283-295.

Tang MS, Pierce JR, Doisy RP, Nazimiec ME and MacLeod MC (1992) Differences and similarities in the repair of two benzo[a]pyrene diol epoxide isomers induced DNA adducts by $u v r A, u v r B$, and $u v r C$ gene products. Biochemistry 31:8429-8436.

Thompson CL, Zadock MC, Lambert JM, Andries MJ and Lucier GW (1989) Relationships among benzo $(\alpha)$ pyrene metabolism, benzo $(\alpha)$-diolepoxide: DNA adduct formation, and sister chromatid exchanges in human lymphocytes from smokers and nonsmokers. Cancer Res 49:6503-6511.

Topinka J, Binkova B and Mrackova G (1997) DNA adducts in human placenta as related to air pollution and to GSTM1 genotype. Mutat Res 390:59-68.

Tucker JD, Auletta A, Cimino MC, Dearfield KL, Jacobson-Kram D, Tice RR and Carrano AV (1993) Sister-chromatid exchange: Second report of the Gene-Tox Program. Mutat Res 297:101-180.

Vineis P and Caporaso N (1995) Tobacco and cancer: Epidemiology and the laboratory. Environ Health Perspect 103:156160.

Wei Q, Gu J, Cheng L, Bondy ML, Jiang H, Hong WK and Spitz MR (1996) Benzo(a)pyrene diol epoxide-induced chromosomal aberrations and risk of lung cancer. Cancer Res 56:3975-3979.

Wiencke JK, Kelsey KT, Lamela RA and Toscano WA (1990) Human glutathione S-transferase deficiency as a marker of 
susceptibility to epoxide-induced cytogenetic damage. Cancer Res 50:1585-1590.

Xiong P, Bondy ML, Li D, Shen H, Wang LE, Singletary SE, Spitz MR and Wei Q (2001) Sensitivity to benzo(a)pyrene diol-epoxide associated with risk of breast cancer in young women and modulation by glutathione S-transferase poly- morphisms: A case-control study. Cancer Res 61:84658469.

Zhong S, Willie AH, Barnes D, Wolf DR and Spurr NK (1993) Relationship between the GSTM1 genetic polymorphism and susceptibility to bladder, breast and colon cancer. Carcinogenesis 14:1821-1824.

Associate Editor: Catarina S. Takahashi 